\title{
MOLECULAR DETECTION OF PSEUDOMONAS AERUGINOSA ISOLATED FROM MINCED MEAT AND STUDIES THE PYOCYANIN EFFECTIVENESS ON PATHOGENIC BACTERIA
}

\author{
D. A. Qasim
}

Market Researches and Consumer Protection Center/ University of Baghdad doaaalani@yahoo.com

\section{ABSTRACT}

This study was aimed to collected Minced meat from the local markets in Baghdad governorate during 2018, and examined for the presence of Pseudomonas aeruginosa, in order to extract and purify pyocyanin and examined it as an antimicrobial activity against pathogenic bacteria in foods. Fifteen isolates were isolated from 50 samples and identified as $P$. aeruginosa using the API20E system and finally confirmed with PCR using 16SrRNA gene. Four tested media were used for the production of pigment after incubation within $72 \mathrm{~h}$, One strain which given a vigorous pigmentation was chosen and extracted with chloroform and $\mathrm{HCl}$ then analyzed with Gas chromatography (GC-Mass) which showed a sharp peak at the time of acquisition of 27.13 minutes at the chromatographic analysis recognized with mass spectrometry as Hemipyocanin (alpha-hydroxy phenazine) which produced molecular ion with intensive peak at $205 \mathrm{~m} / \mathrm{z}$. Agar well diffusion technique was applied for estimating the antimicrobial activity of purified (pyocyanin) with variable concentrations $(25,50,75$ and 100 $\mathrm{mg} / \mathrm{ml}$ ) which monitored toward Gram-negative and Gram-positive bacteria that isolated of minced meat. Escherichia coli and staphylococcus aureus was the most affected with pyocyanin were followed by Serratia marcescens and Klebsiella sp. at the same level. While Enterobacter sp, Bacillus cereus, Proteus mirabilis, and Proteus vulgaris showed intermediate sensitivity, the Pseudomonas fluorescens was shown low sensitivity to pyocyanin.

Keywords: pyocyanin purification, gas chromatography, inhibition zones, 16SrRNA Gene.

قاسم 1207-1199:(4)50:2019- مجلة العلوم الزراعية العراقية

الكثف الجزيئي لبكتريا Pseudomonas aeruginosa المعزولة من اللحم المثروم ودراسة الفعالية البيولوجية لمادة

$$
\begin{aligned}
& \text { البايوسيانين ضد البكتريا المرضية } \\
& \text { دعاء عادل قاسم } \\
& \text { مركز بحوث السوق وحماية المستهلك/ جامعة بغداد }
\end{aligned}
$$

المستخلص

هدفت الدراسة الى جمع اللحوم المفرومة من الأسواق المحلية في محافظة بذاد خلال عام 2018 ، ويحثت عن وجود الزائفة الزنجارية، من أجل استخراج وتنقية البيوسيانين وفحصها كمضاد للميكرويات ضد البكتيريا المسبية للأمراض في الاغذية. تم عزل 15 عزلة من من

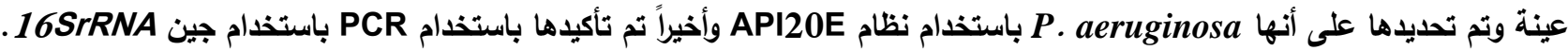
تم استخدام أربعة اوساط زرعيةلانتاج الصبغة بعد الحضانة خلال 72 ساعة، اختيرت سلالة واحدة تعطى تصبغًا قويًا واستخلصت

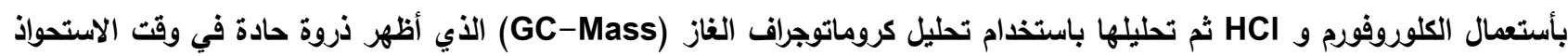
alpha-Hydroxy phenazine دقيقة و التحليل الكروماتوغرافي للغاز الذي تم تحديده بواسطة تحليل الطيف الكتلي باعتباره والذي أعطى ذروة جزيئية مكثفة عند 205 / zemipyocanin) المضاد للميكرويات للنقى (البيوسيانين) بتركيزات مختلفة (25 ، 50 ، 75 و 100 ملغ / مل) وفعاليتها ضد البكتيريا الموجبة لصبغة

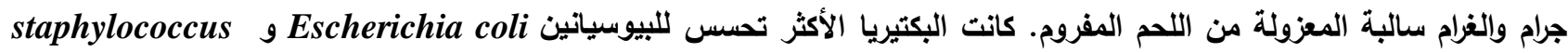

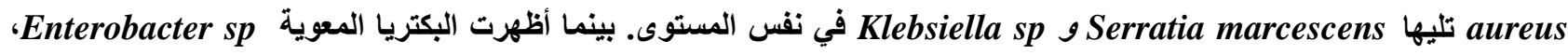
fluorescens - Pseudomonas حساسية متوسطة، أظهر الProteus vulgaris و Proteus mirabilis cereus حساسية ضعيفة للبيوسيانين.

16SrRNA الكلمات المفتاحية: تنقية البيوسيانين, كروماتوجراف الغاز , مناطق تثبيط, جين 


\section{INTRODUCTION}

The shelf life of foods is identified being the period when the food quality remains satisfying within severe conditions of storage, distribution, and display. Spoilage is the method in which food has degenerated and turns into unacceptable for humans being or its quality is diminished turning food improper for selling or consumption (13). Several bacterial isolates which are particular as spoilage organisms (SSO) of meat, fish and poultry that can be identified through the ability for analyzing the nitrogenous components and generating the volatile compounds such as (ketones, esters, and aldehydes) that responsible for the flavor that will be formed at the point of spoilage. Some organisms primarily cause a change in sugars by oxidation and producing alkali and other organisms produce a fluorescent pigment (3). From the total of microflora, Pseudomonas spp. may represent the minority at the beginning of shelf life of the food then become dominant at the end. Phenazines are comprised the most significant extracellular pigments that produce from genus Pseudomonas, $P$. aeruginosa which is rod shape, aerobic and a Gram-negative opportunistic pathogen. Pseudomonas aeruginosa has a distinctive feature through synthesized of the blue-green, chloroform-soluble compound called pyocyanin (1-hydroxy-s-methelphenazine) (9). A number of virulence factors are secreted by $P$. aeruginosa which is considered the physiological and pathological effects of these bacteria. Of these virulence factors, Pyocyanin is phenazine oxidation pigment with lowmolecular-weight that produced by $P$. aeruginosa (14). The Pyocyanin production is regulated by sensing the quorum, which involves a cell-dependent synthesis of signaling molecules that modify the expression of virulence genes (19). In spite of the fact, that pseudomonad has repeatedly been described for its pathogenicity; the capability of these microorganisms to produce antimicrobial pigment has opened the opportunity to an application of this agent as a biological regulator (19). Pyocyanin has antimicrobial activity toward wide different microorganisms, which may assist $P$. aeruginosa through eliminating competing microorganisms; pyocyanin serve as an antimicrobial agent, selectively inhibitors for gram-positive and gram-negative bacteria rather than Pseudomonas spp. The redoxactive phenazine compound (Pyocyanin) which kills bacterial cells by the production of reactive oxygen intermediates. $P$. aeruginosa resists pyocyanin because of the limited redox cycling of this compound and that under conditions favoring pyocyanin production; catalase and superoxide dismutase activities are increased.Researchers created numeral and substantial modern antimicrobial agents within the latest thirty years; simultaneously the resistance of bacteria to the antimicrobial agents has more progressed. The aim of this study is to isolate various isolates of $P$. aeruginosa from minced meat with purifying and discriminate the pyocyanin pigment by conventional methods and study the pyocyanin properties as antimicrobial activity toward some pathogenic bacteria.

\section{MATERIALS AND METHODS}

\section{Sampling}

This survey was carried out during 2018, 50 fresh minced meat samples were randomly collected from Baghdad supermarkets, Iraq. The samples were stored in the ice box while transport to the University of Baghdad/ laboratory of market research and consumer protection center for examination.

\section{Isolation with identification of $\boldsymbol{P}$. aeruginosa and target bacteria from clinical samples}

$P$. aeruginosa is isolated out of minced meat specimens: blood agar, nutrient agar and Pseudomonas Cetrimide Agar (OxoidTM) and selective media for each microorganism. In beginning; Twenty-five gram of freshly minced meat specimens have been homogenized within peptone water $(225 \mathrm{ml})$, samples were later cultivated on selective agar media through streaking and pour plate technique and incubated at $35^{\circ} \mathrm{C}$ within $48 \mathrm{~h}$. (16). Observed the distinguishing pigmentation and compare the physiological and microscopic aspects with biochemical characters of the isolates through the official description presented in "Bergey's Manual of Determinative Bacteriology", that were recognized as $P$. aeruginos then the positive isolates has been confirmed with (API 20E). 
Brain heart infusion agar was used to preserve the pure strains as slants form (16).

\section{DNA extraction}

A genomic DNA of $P$. aeruginosa was extracted for PCR amplification depending on company instruction Kit of DNA (G-spinTm, INtRON, Korea). Bacterial culture was transported to the microcentrifuge tube and Centrifugation at $13.000 \mathrm{rpm}$ for one min, a buffer of Lysozyme was insert into the (centrifuge tube) the lysozyme was completely dissolved by using a vortex, the lytic when finished, the centrifuge was repeated twice and washed with buffer, the extracted DNA was saved at $4^{\circ} \mathrm{C}$ until use. $1.0 \%$ agarose gel was used to Electrophoresis the purified DNA. Five microns of DNA was combined beside three $\mu 1$ loading dye of bromophenol blue then photos were taken through using U. V. light $350 \mathrm{~nm}$ (Sambrook and Russell, 2001).

\section{Detection of $P$. aeruginosa using 16S Rrna}

The specific gene of $16 S$ rRNA was conducted as Partial amplification with applying the primer pairs as in table (1), producing an amplicon with $150 \mathrm{bp}$ with $25 \mu \mathrm{l}$ reactions that including $100 \mathrm{pmol}$ of each primer, master mix was used which is includes (PCR buffer, Taq polymerase, $\mathrm{MgCl} 2$ and dNTPs) and $100 \mathrm{ng}$ of template DNA, with the conditional of amplification: the first denaturation was $95^{\circ} \mathrm{C}$ within 5 min following by 30 cycles of $95^{\circ} \mathrm{C}$ within $30 \mathrm{~s}, 60{ }^{\circ} \mathrm{C}$ within $30 \mathrm{~s}$, and $72{ }^{\circ} \mathrm{C}$ within $45 \mathrm{~s}$, the last extension at $72{ }^{\circ} \mathrm{C}$ within $10 \mathrm{~min}$. PCR amplicons have been analyzed through $2 \%$ agarose gel electrophoresis, then photos were taken through UV transillumination $350 \mathrm{~nm} \quad$ (1). Nanodrop (1000) was used to determine the purity of all $15 P$. aeruginosa extracted DNA and the concentration of DNA was measured with (260/280nm) (1).

Table 1. Primers sequences of $16 S \mathrm{rRNA}$ gene

\begin{tabular}{|cccc|}
\hline Target gene & Primer name & Sequence (5'-3') & $\begin{array}{c}\text { Product } \\
\text { size(bp) }\end{array}$ \\
\hline $\begin{array}{c}\text { 16S } r \text { RNA } \\
\text { gene }\end{array}$ & Pseudomonas-F & 5'-CTACGGGAGGCAGCAGTGG-3' & 150 \\
& Pseudomonas-R & 5'-TCGGTAACGTCAAAACAGCAAAGT-3' &
\end{tabular}

Extraction, purification, and
characterization of the pigment produced by Pseudomonas isolates

The isolates of p.aeruginosa those given a vigorous pigmentation were selected and grown with the broth of Pseudomonas at $37 \mathrm{oC}$ within $48 \mathrm{~h}$ for generation of pigment. The broth culture rich with Pigment was later centrifuged by $(10,000 \mathrm{rpm}$ within $15 \mathrm{~min})$ then the supernatant was accumulated, later filtered within filter membrane pore sized $(0.45 \mu \mathrm{m})$ and applied as the crude extract (7). (Chloroform and $\mathrm{HCl}$ ) was adopting for Extraction of pigment from the crude extract, Chloroform was combined within the broth culture at the proportion of $(2: 1)$. The extract was stirred well by utilizing a shaker for 2 min, then divided out into two discrete layers, one of them was the pigment (a blue solvent layer), and the other was a residual material of culture. The blue layer was accumulated, later solution of $0.1 \mathrm{~N} \mathrm{HCl}(20 \%$ for the blue layer's volume) was combined then vortexed, then generated an upper pink acidified layer. The pink layer was later neutralized by Tris-Base then the neutralized layer was treated with chloroform again. The entire technique was repeated for numerous times to turn into purified pigment (7).

GC-MS Chromatograph of Pseudomonas aeruginosa pyocyanin

Pyocyanin was analyzed by using gas chromatography

(GC-Mass) spectrophotometer with autosampler system (PerkinElmer/USA) this device provided with a carbowax $\left(30^{*} 0.25 \mathrm{~mm}\right.$ ID) and $(0.25 \mu \mathrm{m}$ thickness of film) capillary column (intercut DB5Ms. Japan). One $\mu 1$ of extracted Pyocyanin was autosampler inside the capillary column. The carrier gas (Helium) was adopted. Temperatures of Injector and detector were arranged at $280^{\circ} \mathrm{C}$. The temperature of the column was programmed firstly at $40^{\circ} \mathrm{C}$ to $1 \mathrm{~min}$ and later expands to a $5^{\circ} \mathrm{C}$ rate per min at a terminal temperature of $290^{\circ} \mathrm{C}$. Pigments were separated with at $(96.1$ Kpa) constant pressure and the flow of column $1.71 \mathrm{ml} / \mathrm{min}$. Peaks have been recognized by 
comparing the mass spectra versus the mass spectral database (7).

Screening of $P$. aeruginosa pyocyanin as antimicrobial activity

Antimicrobial activity of pyocyanin toward each isolated bacteria was prepared by using well diffusion technique on Mueller-Hinton Agar following aerobic condition, $100 \mu$ l of bacterial suspension was poured on the surface of MHA spread by L- shape glass rod and left for 10 minutes to settle down the bacteria and $120 \mu \mathrm{l}$ of different concentrations $(25,50,75$ and $100 \mathrm{ppm}$ ) of purified pyocyanin was added to the prepared wells in the same plate and incubated at $37^{\circ} \mathrm{C}$ for $24 \mathrm{~h}-48 \mathrm{~h}$, the diameter of the inhibition zone was measuring around the wells which represent the antimicrobial activity of pyocyanin (6).

\section{Statistical analysis}

The program of Statistical Analysis SystemSAS (18) was employed to perform the different factors in investigation parameters. The LSD (least significant difference) test has been employed to significant compare within the means of this investigation

\section{RESULTS AND DISCUSSION}

Isolation and identification of $\boldsymbol{P}$. aeruginosa The Bacterial isolates that chosen from minced meat sample were cultivated on blood agar and MacConky agar medium, isolates which revealed positive hemolysis activity were elected and re-cultured on nutrient agar and selective agar, these bacterial isolates were identified morphologically and microscopically and the result shown that there are several isolates belong to several genera as in table (2). Out of 50 selected minced meat samples, only 15 strains have been predicted to be $P$. aeruginosa. While the other bacteria were (8 isolates for Psedomonas fluorescens, 24 for Escherichia coli, 13 for Klebsiella sp, 12 for Staphylococcus aureus, 10 for Bacillus cereus, 15 for Proteus mirabilis, 9 for Proteus vulgaris, 11 for Serratia marcescens and 12 isolates for Enterobacter $s p$ ) were chosen as target bacteria. $P$. aeruginosa is human's opportunistic pathogen, relating to the Pseudomonadaceae bacterial family which is popular within the environment; in the clean water, soil, and contaminated food. It has also been widely isolated from fish, meat products and canned food $(4,5)$.

Table 2. Total of bacterial strain isolated from minced meat specimens

\begin{tabular}{|ccc|}
\hline $\begin{array}{c}\text { Bacterial species isolated from 50 fresh } \\
\text { minced meat }\end{array}$ & $\begin{array}{c}\text { NO. of positive } \\
\text { isolates }\end{array}$ & $\begin{array}{c}\text { Percentage (\%)of } \\
\text { positive isolates }\end{array}$ \\
\hline Pseudomonas aeruginosa & 15 & 30 \\
Psedomonas fluorescens & 8 & 16 \\
Escherichia coli & 24 & 48 \\
Klebsiella sp & 13 & 26 \\
Staphylococcus aureus & 12 & 24 \\
Bacillus cereus & 10 & 20 \\
Proteus mirabilis & 15 & 30 \\
Proteus vulgaris & 9 & 18 \\
Serratia marcescens & 11 & 22 \\
Enterobacter sp & 12 & 24 \\
Total isolates & 129 & \\
\hline
\end{tabular}

Morphological and biochemical features confirmed that Pseudomonas aeruginosa is a smooth, large, and irregular bacterium, surrounded by bluish-green coloration with grape-like odor. All the isolates were aerobic, catalase positive, nitrate reduction positive, showed oxidative metabolism on Hugh Leifson medium and the ability to stain with gram stain appear negative when examining microscopically with rods shape, motile. The results of the biochemical characterization, determined by means of the API $20 \mathrm{E}$ for P.aeruginosa in figure (1), those results are consistent with results that observed via (20) who identified Pseudomonas aeruginosa that isolates from food 


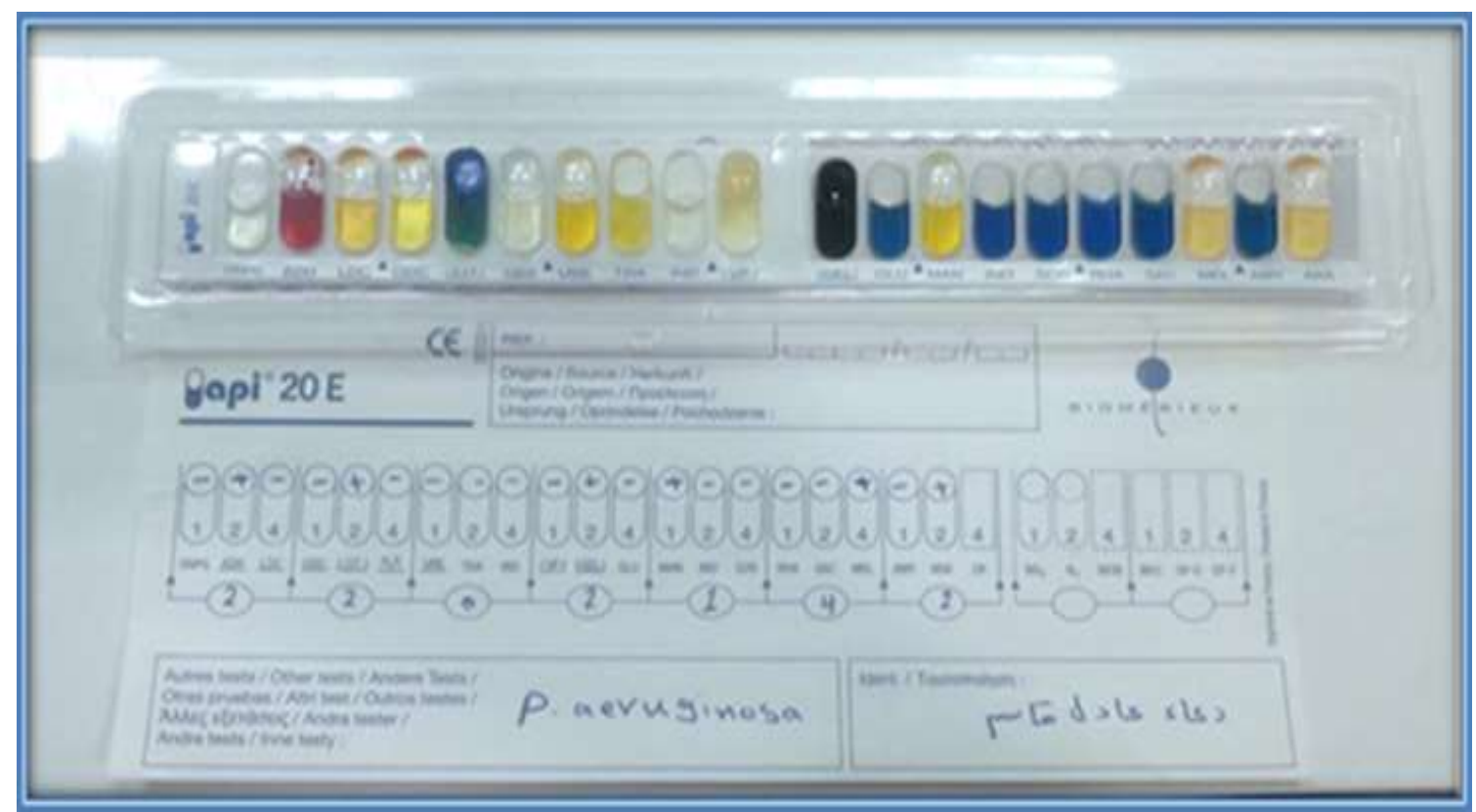

Figure 1. API 20E result of isolated P.aeruginosa Molecular characterization

In the microbiology laboratory, $P$. aeruginosa considered a very common isolate and its identification by conventional biochemical or commercial kits or by automated means may lead to a somewhat expensive process of identification. On the other hand, 24 hours or more may be needed to carry out for identification, so the identification of the Pseudomonas aeruginosa genus was confirmed by tests with the specific primer of $16 S$ rRNA by PCR. The ranges of purity of extracted DNA out of 1.7-2. $350 \mathrm{~nm} \mathrm{U.V} \mathrm{was}$ used for visualized the extracted DNA followed by electrophoresis with $1 \%$ agarose gel by 70 volts within $30 \mathrm{~min}$. The genomic DNA of isolates have been detected with $2.0 \%$ of agarose gel electrophoresis which dyed via red safe stain and electrophoresed in 70 volts about 1:30 hr, the 15 lanes in figure (2) have been captured with ultraviolet $350 \mathrm{~nm}$ (UV) transilluminator with size of band of (150) bp plus (100) bp as DNA ladder and this result was reported previously by (12) study and confirmed by (11).

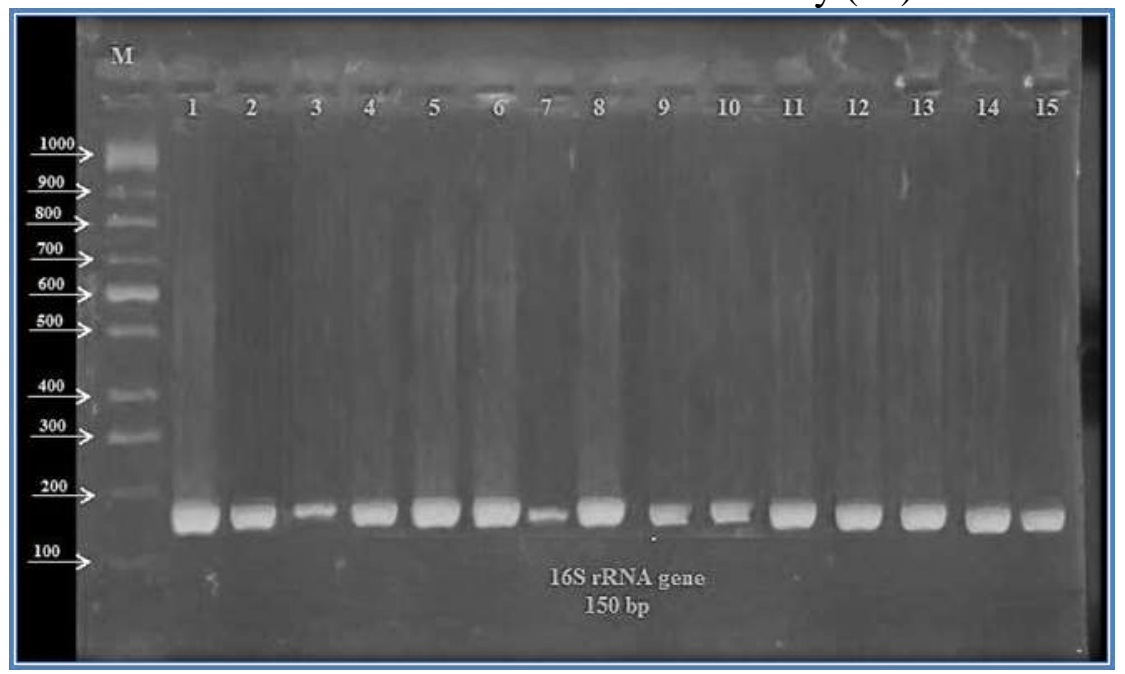

Figure 2. Amplification of $16 S$ rRNA gene with $150 \mathrm{bp}$ on agarose gel of $2 \%$ with 70 volt and

TBE buffer for 1:30 hours. M (100): DNA ladder, lanes (1-15), with $350 \mathrm{~nm} \mathrm{U.V} \mathrm{light}$

The differentiation of the $16 S$ rRNA gene permits comparison at the genus level between organisms of bacteria, as well as to classifying isolates at multiple levels. The $16 \mathrm{~S}$ rRNA gene sequence was noticed by (15) who have analyzed of 5.0 isolates of Pseudomonas contain $99 \%$ nucleotide sequence comparable to $P$. aeruginosa despite its varied considerably in pyocyanin generation.

\section{Production of pyocyanin}

During growth of $P$. aeruginosa on the four tested media; blood agar, nutrient agar, Muller 
Hinton agar, and Mac Conkey agar, it was concluded that there are various nutritional media can be utilized by $P$. aeruginosa for biosynthesis of pyocyanin. During this investigation, it was concluded that the pigment production produce throughout the first 24 hrs of growth and maximal pigment production was reached following $48 \mathrm{hrs}$. While, isolate No. 4 achieved the highest yield after 72 hrs. Among these examined strains, the characteristic of Pigment production was found in the $4(26.6 \%)$ out of 15 strain had this ability to produce pigment vigorously within $48 \mathrm{~h}$ of incubation as in figure (3).

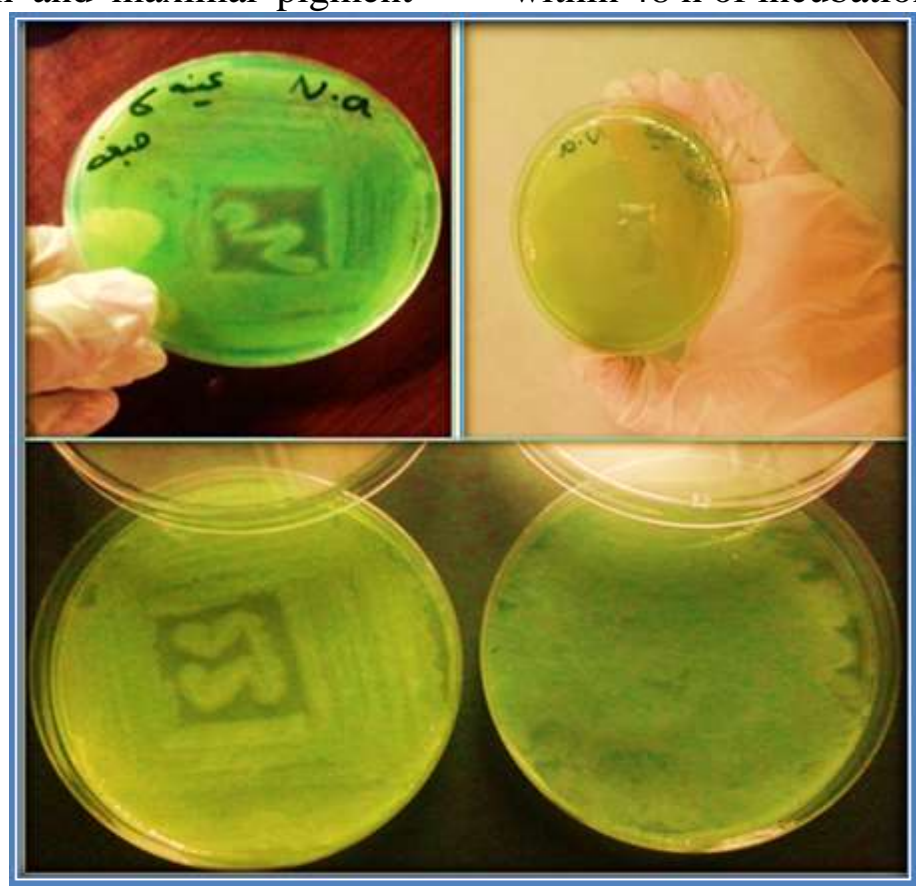

Figure 3. Growth of $\boldsymbol{P}$. aeruginosa on the tested media with produce pigment

Pyocyanin that generated by $P$. aeruginosa is employed in the various clinical microbiological laboratories as an adjunct test in the multiple testing procedures adopted for the identification of $P$. aeruginosa. In preceding researches, the pyocyanin production and catalase activity were enhanced when $P$. aeruginosa was grown in low- and high-phosphate succinate media under conditions of limited Phosphate (10).

\section{Extraction and chemical analysis of} pigment

In the current investigation, a chloroform solvent was the addition for departed of pyocanin from culture supernatants Chloroform extracted layer of pyocyanin showed converter in color from bluish to pinkish red during acidified by $0.1(\mathrm{~N}) \mathrm{HCl}$, which indicated the presence of pyocyanin pigment. Chloroform extracted of P.aeruginosa revealed on gas Chromatographic analysis there is a sharp peak at acquisition period 27.13 minutes that recognized as (Hemipyocanin) alpha-Hydroxy phenazine through mass spectrum analysis which provided intense molecular ion peak at $205 \mathrm{~m} / \mathrm{z}$ and its structure is presented in Figure(4)

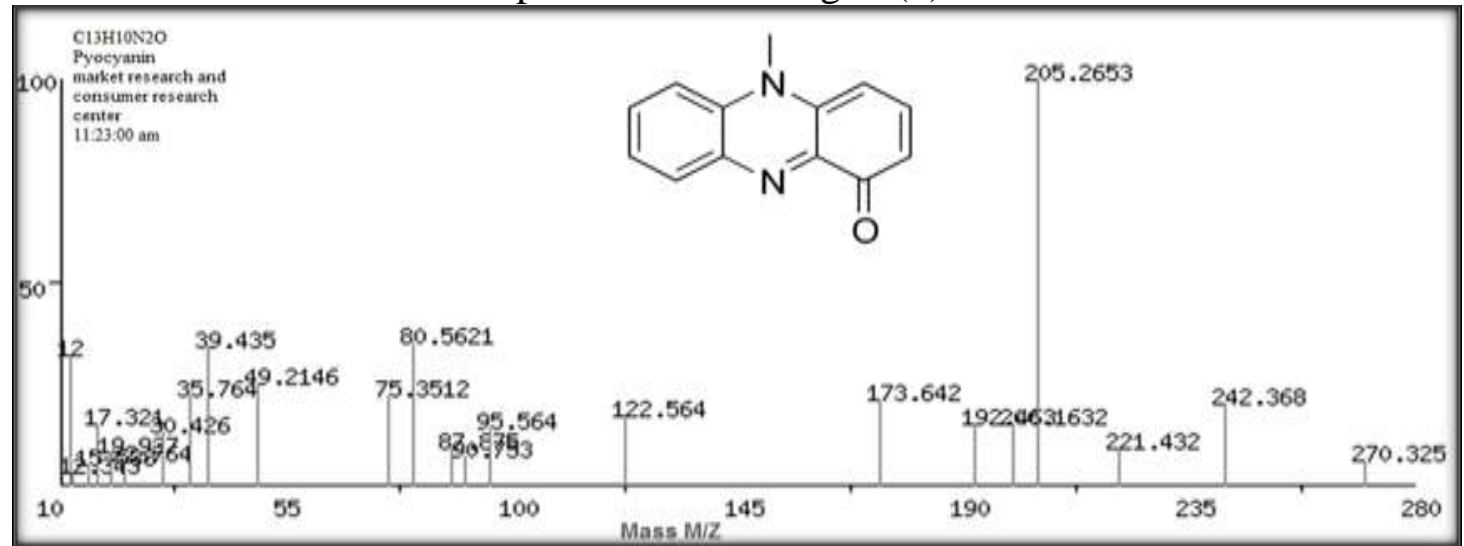

Figure 4. Illustrated the mass spectrum analysis of pyocyanin 
GC-Ms of pyocyanin in the current investigation revealed the existence of phenazine and Hemipyocyanin compound. Prior analysis of GC-Ms by (14) confirmed these result that revealed the correlated hemipyocyanin pigment extracted of $P$. aerogenosa which recognized by mass spectrum following gas chromatography at ions peak $(211 \mathrm{~m} / \mathrm{z})$ while the estimated one is 211.09 for $\mathrm{C} 13 \mathrm{H} 11 \mathrm{~N} 2 \mathrm{O}$. And also consonant with the previous studies of (2) who demonstrated a molecular ion of the protonated purified compound of pyocyanin at m/z 196.

Antimicrobial activity against the target bacteria

The antimicrobial activity of purified pyocyanin at different concentrations $(25,50$,
75 and $100 \mathrm{mg} / \mathrm{ml}$ ) was observed towards Gram-negative and Gram-positive bacteria that isolated out of minced meat. One strain was chosen for the production of (pyocyanin) and estimated for its antibacterial activity by agar well diffusion technique. Out of various concentrations of pigments that used, 25 $\mathrm{mg} / \mathrm{ml}$ revealed less activity with moderate inhibition zone on the agar plate. The remaining concentration of $50-75 \mathrm{mg} / \mathrm{ml}$ revealed the significant obligation with a higher zone of inhibitory activity, while the $100 \mathrm{mg} / \mathrm{ml}$ which is considered the higher concentration and high purity recorded the higher inhibition zone compared with $(25,50$ and $75 \mathrm{mg} / \mathrm{ml}$ ) and the results are presented in table (3) and figure (5).

Table 3. Pyocyanin concentration of P.aeruginosa with Diameter of inhibition zone on target Bacteria

\begin{tabular}{|c|c|c|c|c|c|}
\hline \multirow[t]{2}{*}{ Bacterial isolates } & \multicolumn{4}{|c|}{$\begin{array}{c}\text { Pyocyanin concentration of P.aeruginosa with Diameter of } \\
\text { inhibition zone on target Bacteria }(\mathrm{mm})\end{array}$} & \multirow[t]{2}{*}{ LSD value } \\
\hline & $25 \%$ & $50 \%$ & $75 \%$ & $100 \%$ & \\
\hline Psedomonas fluorescens & $\mathbf{0}$ & 2 & 4 & 7 & $3.63 *$ \\
\hline Escherichia coli & 12 & 18 & 22 & 27 & $5.92 *$ \\
\hline Klebsiella sp & 8 & 11 & 17 & 26 & $5.77 *$ \\
\hline Staphylococcus aureus & 13 & 17 & 22 & 29 & $5.08 *$ \\
\hline Bacillus cereus & 4 & 7 & 11 & 14 & $4.42 *$ \\
\hline Proteus mirabilis & 3 & 6 & 8 & 13 & $4.68 *$ \\
\hline Proteus vulgaris & 4 & 6 & 9 & 11 & $4.09 *$ \\
\hline Serratia marcescens & 7 & 14 & 19 & 24 & $6.16 *$ \\
\hline Enterobacter sp & 5 & 8 & 13 & 17 & $4.51 *$ \\
\hline LSD value & $4.78 *$ & $\begin{array}{l}5.02 * \\
0.05)\end{array}$ & $5.64 *$ & $6.83 *$ & --- \\
\hline
\end{tabular}

The common influenced bacteria to pyocyanin was E. coli and staph.aureus followed by Serratia marcescens and Klebsiella sp. at the same level. While Enterobacter sp, Bacillus cereus, Proteus mirabilis, and Proteus vulgaris showed intermediate sensitivity, the Psedomonas fluorescens was shown a weak low sensitivity to pyocyanin. These conclusions are in accordance with (10) they notify that phenazine compound has antimicrobial activity entirely toward Bacillus subtilis strains and Escherichia Coli. There was a considerable variation of the results regarding the bacterial resistance obtained from different strains and association with pyocyanin of isolated bacteria, This variation refers to the lipid of the cell wall content of Gram-negative and Gram-positive bacteria that may be accountable to the difference for the sensitivity of the pyocyanin antibiotic. Through expanding pyocyanin concentration from $50 \mathrm{mg} / \mathrm{ml}$ to $100 \mathrm{mg} / \mathrm{ml}$, the antimicrobial activity is improved and enhanced; therefore the pyocyanin is concentration dependent as an antibiotic activity. Pyocyanin exhibits as a redox cycle and enhances intracellular oxidant stress and within the aerobic situation. This drives to reactive oxygen species (ROS) generation like hydrogen peroxide, and superoxide, these ROS compounds are able to inhibit the growth of microorganism (8). 


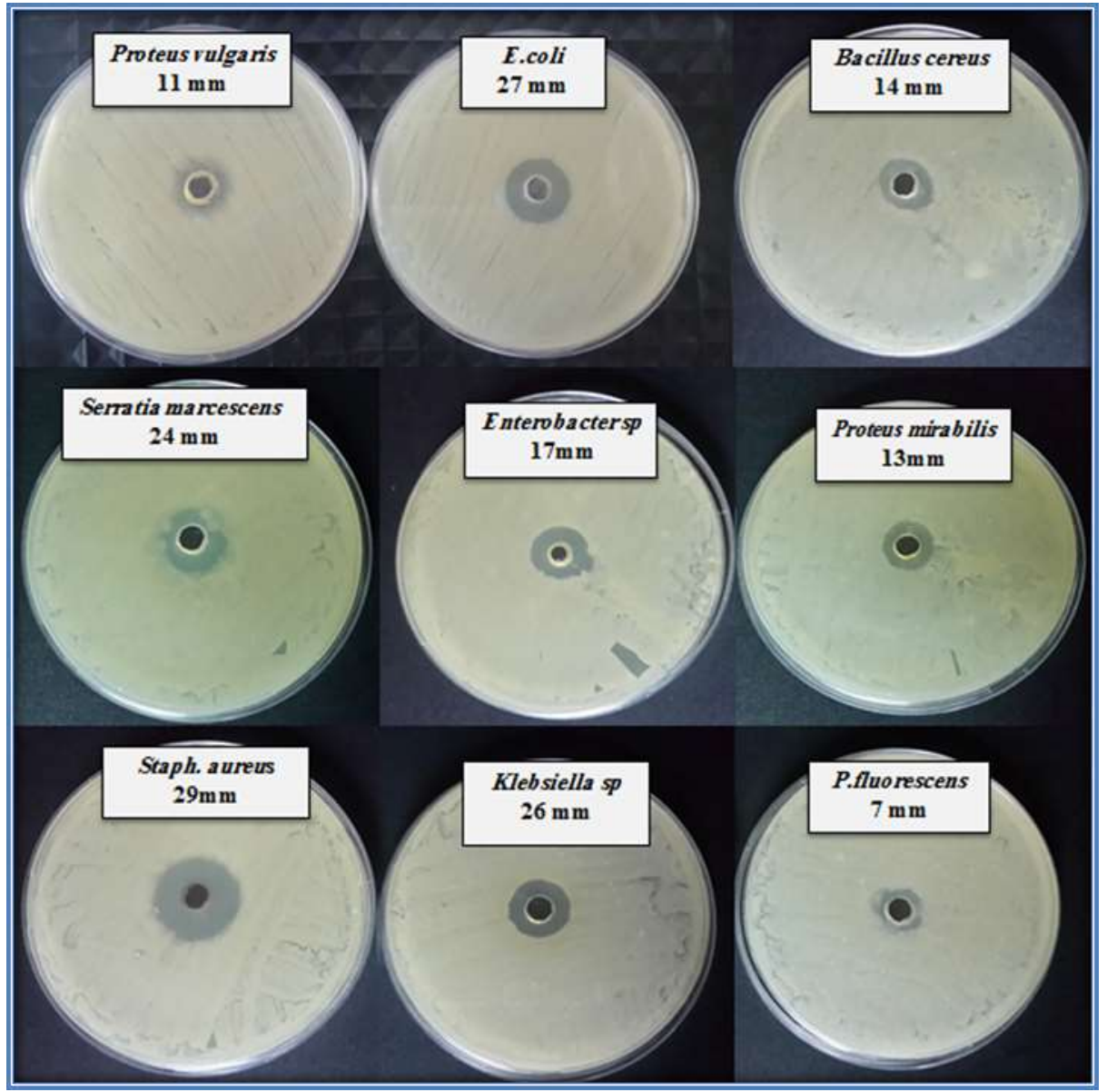

Figure 5. Inhibition zone diameter of purified pyocyanin with concentration $(100 \mathrm{mg} / \mathrm{ml})$ against target bacteria

The current investigation concluded that the pyocyanin which extracted from Pseudomonas aeruginosa isolated out of minced meat was hemipyocyanin and has antimicrobial function as competitive agents infectious and pathogenic bacteria which contaminated food and these could assist as a signal to alert $P$. aeruginosa to the presence of another bacteria and the consequent progressed in pyocyanin production would help $P$. aeruginosa to compete with these microbes and save the food from contamination with pathogenic bacteria.

\section{REFERENCES}

1. Abd El-Aziz, D.M 2015. Detection of Pseudomonas spp. in chicken and fish sold in markets of assiut city, Egypt. Journal of Food Quality and Hazards Control, 2: 86-89

2. Abdul-Hussein, Z. R; and S.S., Atia 2016. Antimicrobial effect of pyocyanin extracted from Pseudomonas aeroginosa. European Journal of Experimental Biology, 6 (3):1-4 3. Alasalvar, C.; F., Shahidi; K., Miyashita; and U., Wanasundara 2011. Handbook of seafood quality, safety and health applications. Blackwell Publishing Ltd, UK

4. Altaai, M.E.; I.H.,Aziz; and A.A., Marhoon 2014. Identification Pseudomonas aeruginosa by $16 s$ rRNA gene for Differentiation from Other Pseudomonas Species that isolated from Patients and environment. Bagh. Sci. Jou, 11 (2): 1028-1034

5. Benie, C.K.; A., Dadié; and A., Guessennd 2017. Characterization of virulence potential of Pseudomonas aeruginosa isolated from bovine meat, fresh fish, and smoked fish. European Journal of Microbiology and Immunology, 7(1):1-10

6. CA-SFM/EUCAST. 2015. European committee on antimicrobial susceptibility testing and antibiogram. Committee of the French Society of Microbiology, 158

7. Cheluvappa, R 2014. Standardized chemical synthesis of Pseudomonas aeruginosa pyocyanin. MethodsX, (1): 67-73

8. Das, T; and M., Manefield 2012. Pyocyanin promotes extracellular DNA release in Pseudomonas aeruginosa. PLoS ONE, 7(4): 67-18 
9. El-Fouly, M.Z.; A.M., Sharaf; A.A.M., Shahin; A. Heba; and A.M.A., El-Bialy 2015. Biosynthesis of pyocyanin pigment by Pseudomonas aeruginosa, Journal of Radiation Research and Applied Sciencess, 8: $36-48$

10. El-Shouny, W.A.; A.R.H., Al-Baidani; and W.T., Hamza 2011. Antimicrobial Activity of Pyocyanin Produced by Pseudomonas aeruginosa isolated from Surgical WoundInfections.

Journal of Pharmaceutical and Medicinal Research, 1(1): 01-07

11. Gholami, A.; A., Majidpour; and M., Talebi-taher 2016. PCR-based assay for the rapid and precise distinction of Pseudomonas aeruginosa from other Pseudomonas species recovered from burns patients. Journal of preventive medicine and hygiene, 57(2):81-85

12. Hassan, I.H.; S.A., Rafik; and K., Mussum 2012. Molecular identification of Pseudomonas aeruginosa isolated from Hospitals in Kurdistan region. Journal of Advanced Medical Research, 2(3): 90-98

13. Jay, J.M.; M.J., Loessner; and D.A., Golden 2005. Modern food microbiology. 7th edition. Springer Science, USA

14. Priyaja, A. 2013. Pyocyanin (5-Methyl-1 Hydroxyphenazine) Produced by Pseudomonas aeruginosa as Antagonist to Vibrios in Aquaculture: Overexpression, Downstream Process and Toxicity (Ph.D. thesis) Cochin Univ. of Science and Technology, India

15. Priyaja, P.; P., Jayesh.; N, Correya., B, Sreelakshmi., N, Sudheer; and R 2014. Antagonistic effect of Pseudomonas aeruginosa isolates from various ecological niches on Vibrio species pathogenic to crustaceans. Journal of Coastal Life Medicine, 2, $76 \mathrm{e} 84$

16. Quinn, P.J.; B.K., Markey; F.C., Leonard; P., Hartigan; S., Fanning; and P.E.S., Fitz2011.Veterinary microbiology and Microbial Disease. 2nd ed. UK: Wiley Blackwell West Sussex, 978(1):118-302

17. Sambrook, J; and D., Russell 2001. Molecular cloning: a laboratory manual 3rd. cold Spring Harbork, New York: cold spring laboratory

18. SAS. 2012. Statistical Analysis System, User's Guide. Statistical. Version $9.1^{\text {th }} \mathrm{ed}$. SAS. Inst. Inc. Cary. N.C. USA

19. Sudhakar, T.; S., Karpagam; and S., Shiyama 2013. Analysis of pyocyanin compound and its antagonistic activity against phytopathogens, International Journal of Chemistry Research, 5: 1101-1106

20. Virupakshaiah, D.B.M; and V.B., Hemalata 2016. Molecular identification of Pseudomonas aeruginosa from food borne isolates. International journal of current microbiology and applied science, 5(6):1026-1032. 